\title{
correspondence
}

\section{How accurate was the carat?}

SIR, - The carat, a well known jeweller's measure of weight, is generally defined as the weight of a seed of the carob tree (Ceratonia siliqua; Leguminosae) or about $200 \mathrm{mg}$ (Webster's New World Dictionary). It is traditional to view seeds as having very low intra specific variation in weight, and therefore not surprising to find them used as standards of commercial weight. But how reliable was this species of seed as a standard?

The carob is a small tree native to North Africa and has the largest dry and hard seed of any Mediterranean plant. In September 1978, I haphazardly collected 12 freshly fallen pods from the ground below a healthy carob tree growing in a courtyard of the Hebrew University, Jerusalem. In April 1979, the seeds were removed from the indehiscent pods and weighed. There were ten seeds that weighed only 0.07 to $0.13 \mathrm{~g}$, and I discarded these seeds from further analysis because they were variously malformed and would be noticed by any discerning merchant or shopper. The remaining 156 seeds could not be sorted into groups of heavier or lighter seeds, and this set had a mean weight of $0.198 \mathrm{~g}$ (s.d. $=0.024$ ), remarkably close to the supposed weight of the carat.

However, there is no reason to believe a merchant would be so stupid as to use average (randomly selected) carob seeds as balance weights. There were 48 seeds ( $31 \%$ ) in the sample that looked normal but weighed less than $0.2 \mathrm{~g}$. All a merchant would have to do is use a gravitational sorting system on a large sample of seeds to obtain a pool of carob seeds up to $25 \%$ underweight to use when making sales. The other end of the weight distribution contained $64(41 \%)$ that weighed 0.21 to 0.24 g. These heavy seeds would have been most useful when making purchases. In short, only $28 \%$ of the seeds in a carob seed crop would have given an honest measure. This study was supported by a subsidy from the Israeli government.

$$
\text { Yours faithfully, }
$$

DANIEL H. JANZEN University of Pennsylvania, Philadelphia, Pennsylvania, USA.

\section{Science is not all whizz}

SIR, - Few would disagree with your leader article (10 May, page 89) that science in the UK is depressed. More precisely, scientists who have chosen to make a career in research are depressed. The danger is that the full effects of the lack of career structure for research scientists has not yet made sufficient impact on scientific output in this country to force any action on the problem. By the time it does, it may be too late. The experienced scientists who should play a major part in research teams of the future will have been dropped by the wayside because research councils and charities are no longer prepared to take on the "burden" (as they describe it) of funding the older person.

Your challenge to the new government to find effective, creative employment for welcomed. But is it centres for "whizz-kids", that we really need? Advancement in scientific rather a methodical and pains-taking approach. Most research scientists are ordinary men and women of average intellect trying to do a job like any other professional. How good they are at their job depends critically on the kind of training they have received. It is about time we got away from the notion that only geniuses can produce good science, and the corollary, that only scientists of "exceptional ability" should be funded. We are not arguing for the support of mediocrity, merely the acknowledgement that scientific research, like other professional careers, should have room for a wide variety of people with differing abilities and contributions to make, not just jobs for "whizz-kids".

\section{Yours faithfully,}

ARMS, Guy's Hospital, London SUSAN BARI OW

\section{Physics and Ghana}

SIR, - Your article (10 May, pages 96-97) rightly emphasised the relative irrelevance of electron transport in thin manganese films to scientific problems in Ghana.

However, as the supervisor of the physicist concerned during his studies, partly in Ghana

\section{Nuclear power does not lead to nuclear weapons}

SIR, - Professor Rotblat with his phrase "the life blood of modern society" (31 May, page 370 ), recognises the need for adequate energy supplies, yet he seems reluctant to accept that nuclear power should make a contribution.

Even though his proposed World Energy Organisation would (inter alia) "'advise countries of the type of energy most suitable for them - including nuclear if deemed necessary", Professor Rotblat's obsession with the proliferation of nuclear weapons, the extreme views he put forward in his lecture as reported in Nature, 1 March, page 4 ("In the long run nuclear energy is not compatible with the survival of civilisation") and his hostility towards the IAEA make it clear that nuclear power would play little part in his WEO.

Although my arguments (26 Aprii, page 776) have failed to convince Professor: Rotblat, the facts seem plain. There is no cas'e where a country has developed nuclear $\epsilon$ xplosives by diverting material from a civil power station. In the ten year period 1945-54 three countries (USA, USSR and UK) developed nuclear explosives; between 1955 and 1964 another two countries (France and China) and between 1965 and 1974 onc further country (India). Over this same time span the world riuclear generating capacity grew, and by 197.4 there were 54,000 MW in operation in 19 countries. There are now $100,000 \mathrm{MW}$ in operation in 22 countries, and if stations under construction are also included, the figures rise to $400,000 \mathrm{MW}$ in 33 and partly at Sussex cn a faculty exchange, would like to add that we also carried out an extensive literature search and correspondence with the Timber Research Association relating to possible physic's-based problems in Ghanaian forestry. These formed the basis of many long discussions during his time at Sussex.

$$
\text { Yours faithfully, }
$$

University of Sussex, UK.

\section{DPAG, GMAG and the trade unions}

SIR, - Reg Bird (26 April, page 776) uses the argument that, because a fatal accident occurred under the supervision of DPAG, which has no trades' union nominees, whereas no comparable accident has occurred under GMAG, which has TUC nominees, therefore the accident free record of GMAG is a consequence of this presence. It seems a pity that fallacious reasoning which would never appear in your scientific papers is allowed to exist in your correspondence columns. Yours faithfully,

ALAN D. B. MaLCOLM

St Mary's Hospital Medical School, London, UK.

countries. This indicates that there is no direct link between peaceful nuclear power and nuclear weapons. This point comes out even more clearly when it can be shown that for each of the five nuclear weapon states the explosion of their first bomb preceded, not followed, the entry into service of their first prototype commercial power reactors (Table 1).

The plutonium for the Indian nuclear explosion of 1974 was obtained from a research reactor. In addition it is widely believed that Israel and South Africa are probably capable of making nuclear weapons, but neither country has a commercial nuclear power station in operation.

It could be argued that the greater a country's dependence on nuclear energy for essential electricity the less likely it would be to jeopardise its relations with international suppliers by breaking international agreements. Quite contrary to the innuendo of Professor Rotblat's final sentence, most nations have not become nuclear weapon states: 104 of them have acceded to the NonProliferation Treaty.

It is essential that every effort is made to find ways to prevent the misuse of nuclear energy; a refusal to accept its benefits is not one of them.

$$
\text { Yours faithfully, }
$$

G. H. GREENHALGH

A Power for Good,

London, UK.

Table I Dates of first nuclear bomb and first nuclear reactor for the five nuclear weapon states Britain's postdoctoral fellows is to be research rarely requires the flash of genius, but
Country

USA................

USSR...............

UK ...............

France..............

China............

Date of first bomb
exploded in
atmosphere
1945
1949
1952
1960
1964

Date of first prototype power reactor in service 1957

1958

1956

1964

No firm evidence of a power reactor in service

\section{Commercial name \\ Shippingport \\ Troitsk \\ Calder $\mathrm{Hal}$ \\ Chinon}

$0028-0836 / 79 / 270010-0150100$ 